\title{
Reducing Disruptive Classroom Behaviors: The Effect of Group Counseling With Self-Management
}

\author{
Sri Rahmah Ramadhoni ${ }^{1}$, Mungin Eddy Wibowo ${ }^{2}$, Muhammad Japar ${ }^{3}$ \\ \{ sriramadhoni@students.unnes.ac.id ${ }^{1}$, mungineddy@mail.unnes.ac.id ${ }^{2}$, \\ m.jafar_umm@yahoo.com ${ }^{3}$ \}
}

Universitas Negeri Semarang, Indonesia $^{1,2}$, Universitas Muhammadiyah Magelang, Indonesia ${ }^{3}$

\begin{abstract}
The Disruptive classroom behaviors are considered the most commonly reported behavioral problems during early adolescence. The purpose of this study is to determine the effectiveness of group counseling with self-management to reduce disruptive classroom behaviors. The research method is an experiment using the design of one group pre-test and post-test. The data collection used was statistical disruptive classroom behaviors. Paired sample t-test results showed that the self-management was effective to reduce disruptive classroom behaviors of junior high school students $(t=10.390, \mathrm{p}<0.01)$. The research found that group counseling with self-management decreased disruptive classroom behaviors of students. The contribution in this study lies in a unique framework that is in the process of providing assistance in trying and being responsible for changing and developing their own behavior using group counseling with self-management.
\end{abstract}

Keywords: Disruptive Classroom Behaviors, Group Counseling, Self-Management

\section{Introduction}

Disruptive classroom behaviors are considered the most commonly reported behavioral problems during early adolescence [1]. The emergence of disruptive classroom behaviors is one of the most important problems faced by the education system, indicated by a large number of studies published in Spain [2]. In Indonesia, disruptive classroom behaviors are rarely discussed even though the frequency and intensity are actually quite high but rarely reported because of the teacher's ignorance [3].

In many studies, disruptive classroom behaviors (DCB) are negatively affected by the learning and teaching environment In accordance with Geddes' research disruptive classroom behaviours (DCB) negatively affect class climate and academic achievement. Teachers who are unable to manage this kind of behaviour fail to facilitate good learning conditions for their students [4][5]. Referring to the disruptive classroom behaviors, many students do not pay attention to the lesson when the teacher explains the lesson, makes noise, disturbs peers, and delays the class for no reason. For reducing the disruptive classroom behaviors, students need the right technique, one of the alternatives is by using self-management through group counseling.

The group approach gives an effective way to facilitate cognitive behavioral interventions for students who show disruptive classroom behaviors [6]. Group counseling is oriented to individual development and makes strengths that originate in individuals by utilizing group dynamics [7]. One reason why cognitive behavioral group work can be an attractive intervention 
for adolescents who show disruptive classroom behaviors is that it uses peer influence to benefit other participants who want to solve their problems [8]. Self-management one of the techniques in cognitive behavior. Self-management interventions were effective in reducing problem behaviour and positively improving social and academic behaviour [9][10]. However, selfmanagement to individuals failed by not being implemented with consistency. This study does not apply the elements of strategy consistently [11].

There have been many studies using self-management strategies in addressing student problems, but there have been no studies to reduce students' disruptive classroom behaviours with self-management strategies. Considering the disruptive classroom behavior research in Indonesia is still rarely done.

Based on the problems of disruptive classroom behaviours carried out by students, it is important to implement a self-management strategy as an effort for counselors to carry out their main tasks through guidance and counseling services in the implementation of the 2013 curriculum to achieve national education goals.

\section{Methods}

This research used one one group post-test design, which consists of one group that has high disruptive classroom behaviors then given treatment in the form of group counseling with self-management. The study sample was seven students of the disruptive classroom behaviors group who were selected purposively from 85 students of of Junior High School An-Nur Tangkit, Muaro Jambi.

Table 1. The Systemic of group counseling with self-management

\begin{tabular}{|c|c|}
\hline Session & Activities \\
\hline 1 & $\begin{array}{l}\text { Delivering understanding related to upcoming activities, building an interpersonal } \\
\text { relationship, and collaborative cooperation, discussing changes in behavior. }\end{array}$ \\
\hline 2 & $\begin{array}{l}\text { Explaining self management principles to strengthen group members' beliefs. } \\
\text { Analyzing clients' behavior in a situation full of pressure and causes disruptive } \\
\text { classroom behaviors. }\end{array}$ \\
\hline 3 & $\begin{array}{l}\text { Inviting group members to understand or reflecting the relationship between } \\
\text { thoughts and feeling to build up awareness. Monitoring disruptive classroom } \\
\text { behaviors, observing the focus shifting of client thoughts and behavior which } \\
\text { harm themselves and transforming it into preventive form. All those behaviors } \\
\text { were developed for counselees. }\end{array}$ \\
\hline 4 & $\begin{array}{l}\text { Controlling posistive behaviors that were applicable in the real-life situation, } \\
\text { transferring negative behaviors to stimulus control positive behavior. These steps } \\
\text { trained clients to move on from disruptive classroom behaviors causes to } \\
\text { positive behaviors. }\end{array}$ \\
\hline 5 & $\begin{array}{l}\text { Creating self-reward to achieve goals, training positive reinforcement by having } \\
\text { counselors as the model and clients practicing positive self-expression with the } \\
\text { aim of appreciating every achievement. }\end{array}$ \\
\hline 6 & $\begin{array}{l}\text { Delivering what has been achieved by the group members and having a } \\
\text { discussion } \\
\text { about objective data. Giving homework and follow-up to make clients practice } \\
\text { skills obtained from SM in the real-life situation }\end{array}$ \\
\hline
\end{tabular}

Data collection techniques used in this study are using a disruptive classroom behaviors 
scale consisting of 28 statement items. Based on the validation results of the testing, and the reliability of items, it shows that the initial disruptive classroom behaviors scale amounted to 36 items, 28 items were declared valid, and 8 items were declared invalid. The reliability test results show the disruptive classroom behaviors scale with the Alpha formula has a coefficient of 0.93 . The session of group counseling with self-management to reduce disruptive classroom behaviors was done six times. Each session had 80 minutes time allotment.

\section{Results and Discussion}

The collected data (pretest-posttest) was tabulated and prepared before then analyzed. The condition of disruptive classroom behaviors by involving 7 students. After getting the intervention, the level of student disruptive classroom behaviors decreased in each group, changes in scores can be seen (Table 2).

Table 2. Changing patterns of decreasing levels of disruptive classroom behaviors

\begin{tabular}{ccclccc}
\hline Student & $\begin{array}{c}\text { Pretest } \\
\text { Score }\end{array}$ & $\%$ & Criteria & $\begin{array}{c}\text { Posttest } \\
\text { Score }\end{array}$ & $\%$ & Criteria \\
\hline SM & & & & & & \\
Group & 82 & $73 \%$ & Tinggi & 63 & $50 \%$ & Sedang \\
HL & 94 & $84 \%$ & Tinggi & 64 & $51 \%$ & Sedang \\
BR & 80 & $71 \%$ & Tinggi & 61 & $49 \%$ & Sedang \\
DJ & 90 & $80 \%$ & Tinggi & 65 & $52 \%$ & Sedang \\
MS & 80 & $71 \%$ & Tinggi & 67 & $53 \%$ & Sedang \\
ZEF & 86 & $77 \%$ & Tinggi & 60 & $48 \%$ & Rendah \\
TFR & 86 & $77 \%$ & Tinggi & 61 & $49 \%$ & Sedang \\
RDS & & & & & & \\
Mean & 85.43 & $(5.255)$ & & 63.00 & $(2.517)$ & \\
(SD)= & & & & & & \\
\hline
\end{tabular}

Analysis of the results showed that the mean of pre-test of student disruptive classroom behaviors was 85.43 with SD 5.255, while at the post-test the mean was 63.00 with SD 2.517. It can be seen that there is a difference in the average value of the pre-test and post-test which shows that there is a change in students' disruptive classroom behaviors decrease after getting self-management group counseling.

Table 3. Mean and SD of students' disruptive classroom behaviors

\begin{tabular}{ccc}
\hline Tabsesment & M & SD \\
\hline Pre-test & 85.43 & 5.255 \\
Post-test & 63.00 & 2.517 \\
$\mathrm{t}$ & 10.390 & \\
$\mathrm{p}$ & $<0.01$ & \\
\hline
\end{tabular}

In line with the results of pre-test and post-test measurements, it can be seen that there is a decrease in the level of disruptive classroom behaviors of students. This means that selfmanagement technique group counseling is effective to reduce disruptive classroom behaviors 
of junior high school students. The results of the t-test analysis, paired sample t-test confirms that self-management technique group counseling can be applied to school students $(t=, 10.390$ $\mathrm{p}<0.01)$.

The emergence of disruptive classroom behaviors is one of the most important problems faced by the education system because high disruptive classroom behaviors (DCB) will have a negative impact on individuals (students) in school. Counseling groups of self-management techniques are group counseling with a change, and development strategy that emphasizes effort, and personal responsibility to change, and develop their own behavior. Changing this behavior in the process is mostly done by students, while counselors provide treatment in group counseling interventions.

The results of the study explain the application of self-management in effective group counseling to improve academic behavior. The application of self-management as an intervention, in general, can be understood, feasible and desired by students [12]. Furthermore, that learning responsibilities can be improved through counseling individuals with selfmanagement techniques on accounting class XI students at Pemalang N 1 SMK by making an effective contribution of $2.20 \%$ [13].

Some educational influences and parental personality on children's disruptive behavior, and the aggressive aspects of parental personality had a major effect on children's disruptive behavior, followed by conformity, respect, and at the lowest level, the aspect of dominance [14]. In relation the effectiveness of group counseling with self-managementtechniques to improve the learning independence of middle school students [15]. Furthermore, the group counseling model of self-management techniques was effective in improving students' self-concept [16].

In the counseling process, students' self-management techniques are directed to determine the target behavior that they want to change. Students conduct an evaluation with selfmonitoring, namely making a note of the behavior that appears, and has been achieved in accordance with the target set. Students also record any insights, and difficulties experienced when in the process of achieving the set of behavioral targets. This result can be achieved because of the awareness, and intention of the students themselves to reduce disruptive classroom behaviors by taking part in self-management techniques seriously, and enthusiastically. In addition, self-management techniques can help students change the behavior that is considered detrimental to emphasize the help of others. Group counseling with selfmanagement implemented in Junior High School An-Nur Tangkit Muaro Jambi showed effectiveness in reducing disruptive classroom behaviors of junior high school students.

\section{Conclusion}

This research was conducted to reduce students' disruptive classroom behaviors through group counseling with self-management. The results of this study indicate that group counseling with self-management can significantly reduce disruptive classroom behaviors of junior high school students. School counselors are expected to continue to develop their competencies, especially in providing group counseling to reduce disruptive classroom behaviors of junior high school students. Further researchers are expected to be able to use group counseling with self-management but with different problems, approaches, and research subjects.

\section{References}

[1] Tyler, K. M., Burris, J. L., \& Coleman, S. T.: Investigating the Association Between Home-School 
Dissonance and Disruptive Classroom Behaviors for Urban Middle School Students. Journal of Early Adolescence. pp. 1-24 (2016)\

[2] Martino, E. Á., Hernández, M. Á., Pañeda, P. C., Ángel, M., \& Mon, C.: Teachers' perception of disruptive behaviour in the classrooms, Vol. 28(2), pp.174-180 (2016)

[3] Wicaksono, T. H.: Perilaku Mengganggu di Kelas. Paradigma, Vol. 15(VIII), pp.115-130 (2013)

[4] Sezer, S.: Novice Teachers' Opinions on Students' Disruptive Behaviours: A Case Study. Eurasian Journal of Educational Research, 69, pp.199-219 (2017)

[5] Duesund, L., \& Ødegård, M.: Students , perception of reactions towards disruptive behaviour in Norwegian and American schools. Emotional and Behavioural Difficulties, pp.1-14 (2018)

[6] Larmar, S.: The use of cognitive therapy as a means of facilitating cognitive behavioural instruction for adolescents with disruptive behaviour. Australian Journal of Guidance and Counselling, 16, pp.233-248 (2006)

[7] Wibowo. M. E. (2019). Konseling Kelompok Perkembangan. Semarang: UNNES PRESS.

[8] Burton, S.: Over to you: Group work to help pupils avoid school exclusion. Educational Psychology in Practice, 22, pp.215-236 (2006)

[9] Hansen, B. D., Wills, H. P., Kamps, D. M., \& Greenwood, C. R.: The Effects of Function-Based SelfManagement Interventions on Student Behavior. Journal of Emotional and Behavioral Disorders, 22(3), pp.149159 (2014)

[10] Shogren, K. A., Lang, R., Machalicek, W., Rispoli, M. J., \& Reilly, M. O.: Self-Versus Teacher Management of Behavior for Elementary School Students With Asperger Syndrome: Impact on Classroom Behavior. Journal of Positive Behavior Interventions, 13(2), 87-96 (2011)

[11] Thompson, A. M.: A Randomized Trial of the Self-Management Training and Regulation Strategy for Disruptive Students. Research on Social Work Practice, 24(4), pp.414-427 (2014)

[12] Briesch, A. M., \& Chafouleas, S. M.: Review and analysis of literature on self-management interventions to promote appropriate classroom behaviors (1988-2008). School Psychology Quarterly, 24, pp.106-118 (2009) [13] Ulfa Dinia, Wibowo, M.E., \& Sugiyo.: Meningkatkan Tanggung Jawab Belajar dengan Layanan Konseling Individual Teknik Self Management. Indonesian Journal Guidance and Counseling: Theory and Application. 3(4): pp.22-30 (2014)

[14] Purwati \& Japar, M.: Parents' Education, Personality, and Their Children's Disruptive Behaviour. International Journal of Instruction, 10(3), pp. 227-240. (2017).

[15] Puspitasari, Y. S. D., Sugiyo, \& Wibowo, M. E.: The effectiveness of group counseling with selfmanagement techniques to improve the student learning independence. Jurnal Bimbingan Konseling, 8(1), pp. 15 (2019)

[16] Aisah, F. N., Wibowo, M. E., \& Purwanto, E.: Pengembangan model konseling kelompok teknik selfmanagement untuk meningkatkan konsep diri siswa. Jurnal Bimbingan Konseling, 6(2), pp.147-153. (2017) 